\title{
The Second Passover, Pilgrimage, and the Centralized Cult ${ }^{*}$
}

\author{
Simeon Chavel \\ Princeton University
}

The passage in Numbers 9:1-14 presents new legislation on the Passover sacrifice. For one who contracted impurity immediately prior to the Passover or was too far away to participate in it, the amendment prescribes an alternate date, one month later:

When any of you or your posterity who are defiled by a corpse or are on a long journey would offer a passover sacrifice to the Lord, they shall offer it in the second month, on the fourteenth day of the month, at twilight (vv. $10-11)$.

In 1899, Arnold Ehrlich pinpointed this legal innovation as "a novella without parallel in the entire Pentateuch" - and justly so. ${ }^{1}$ The idea that for personal reasons an individual may defer a calendrically defined rite, miss a monumental date in the history of the nation and make it up some typological thirty days later, flies in the face of the significance of time to the potency of ritual. ${ }^{2}$ Indeed, the law of the Second Passover stands alone, not only in the Hebrew Bible, but also, apparently,

* It is with gratitude and appreciation that I note that the preparation of this article was made possible by a grant from the Memorial Foundation for Jewish Culture. An early draft was presented at the Hebrew Bible Seminar at Harvard University, February 2006. Sincere thanks to the editors of HTR for their helpful comments. English citations of biblical passages come from Tanakh-The Holy Scriptures: The New JPS Translation According to the Traditional Hebrew Text (Philadelphia: The Jewish Publication Society, 1985), except where otherwise noted.

${ }^{1}$ Arnold Ehrlich, Scripture in Its Plain Sense (3 vols.; Berlin: M. Poppelauer Buchhandlung, 1899-1901) 1:254 [Hebrew].

${ }^{2}$ For one brief critical review of Mircea Eliade's foundational work in this area, see Jonathan Z. Smith, Map Is Not Territory: Studies in the History of Religions (Chicago: University of Chicago Press, 1978) 88-103. For the extreme example of the Passover as the sole focalizing moment of an entire calendar in early Christianity, see the citation and discussion in idem, To Take Place: Toward Theory in Ritual (Chicago: University of Chicago Press, 1987) 88.

HTR 102:1 (2009) 1-24 
in the ancient Near East and beyond. ${ }^{3}$ Hittite law, for that matter, explicitly forbids just this scenario:

You who (are) the temple officials: If you do not perform the festivals at the time of the festivals; (if) you do the spring festival in fall, (or) the fall festival in spring, (or) if the right time for doing the festival (has) arrived, and he who is to do it comes to you ... . and he seizes your knees, (saying) "The harvests (are) before me," or a marriage or a journey or some other matter. "Let me off. Let that matter finish for me, and when that matter is finished for me, I will do the festival thus": Do not do according to the wishes of (that) man. He must not persuade you. Do not conduct business concerning the will of the gods. ${ }^{4}$

The temple functionary who, baited by a bribe, succumbs to such a request will suffer the consequences:

(If) a man persuades you, and you take payment for yourselves, the gods will demand it of you at a later time. They will stand in evil against your spirit, wives, children, (and) servants. ${ }^{5}$

With regard to the Second Passover, an added level of complexity or even irony comes from the fact that the primary text instituting the Passover, Exod 12:1-24, forges an organic link between the Passover and the new calendar that will constitute the nation of Israel ever after: "This month is hereby for you the first of the months; it is the first, for you, of all the months of the year . . . on the tenth of this month,

${ }^{3}$ See Mark E. Cohen, The Cultic Calendars of the Ancient Near East (Bethesda, Md.: CDL, 1993). According to the standard interpretation of 2 Macc 10:5-8, the Maccabees modeled their temple inauguration on the Festival of Sukkot, which they had been forced to forego only shortly before, and the letter in 1:1-9 refers to the festival celebrated thereafter as "the Festival of Booths." At the very least, it would go far beyond the evidence to infer that Hanukkah served essentially as an annual opportunity to make up a missed Festival of Booths. Joseph Tabory does not make much of these references for a reconstruction of the original Hanukkah, or of the opinions he conveniently collects that do; see his Jewish Festivals in the Time of the Mishnah and Talmud (3rd ed.; Jerusalem: Magnes, 2000) 374-75 [Hebrew]. In a similar spirit, see Uriel Rappaport, The First Book of Maccabees (Jerusalem: Yad Ben-Zvi, 2004) 78 [Hebrew]. Daniel Schwartz sees 2 Macc 10:5-8 as an interpolation by the author of the letters in the first two chapters, and refers to it as "an early interpretation" of Hanukkah; see his The Second Book of Maccabees (Jerusalem: Yad Ben-Zvi, 2004) 14-16, 289-95 [Hebrew]. For an argument against these texts making any reference at all to the Pentateuch's Feast of Tabernacles, see Moshe Benovitz's online piece [in Hebrew] at http://www.schechter.ac.il/bima. asp? $\mathrm{ID}=35$ (a more detailed, scholarly version, in print, is in preparation).

4 "Instructions to Priests and Temple Officials, 9," in The Context of Scripture, Volume One: Canonical Compositions from the Biblical World (ed. William W. Hallo and K. Lawson Younger, Jr.; trans. G. McMahon; Leiden: Brill, 2003) 217-21, at 219. McMahon notes that the verb he has rendered as "persuade" (loosely, apparently, to judge by his use of italics) is the medio-passive "to see." This idiom appears throughout the ancient Near East in the context of visiting king (= doing homage or seeking audience) or deity (= pilgrimage), often with attending gifts. In this context, it would seem that when the Hittite law speaks of "conducting business" it has these gifts in mind, and envisions the farmer offering some kind of a bribe, perhaps in the form of a donation to the temple.

${ }^{5}$ Ibid. 
they should take each one a lamb." The irony would appear to thicken in light of the framing narrative, which dates the law of the Second Passover to the very first turn of the new national calendar, one year after the exodus from Egypt (Num 9:1). ${ }^{6}$

According to the larger narrative that provides the setting for the law, when the time came to begin preparing for the first Passover since the exodus, several people stepped forward with the problem that they had contracted impurity, which would exclude them from the proceedings (Num 9:1-8). God responded with the new law. Tight parallels with Lev 24:10-23; Num 15:32-36; 27:1-11 (also 36:1-12) - in terms of structure, terminology, plot, characterization, and conception of jurisgenesis - illuminate the passage as cast in a highly stylized mold. ${ }^{7}$ Scholars have unanimously identified the passage in its entirety, along with its parallels, as part of the Priestly literature. ${ }^{8}$

Taken together, the mythic setting in the wilderness, the stylized, abstract character of the novella, and the Priestly source of the Second Passover pericope all indicate its fundamentally unhistorical nature. Setting aside, then, the current narrative frame, what were the historical circumstances that led to the development of this rare law of an untimely, deferred Passover, and what was its purpose? ${ }^{9}$ Over the years, scholarship has put forward only a few theories. The first two sections of this paper will offer a critical review of the two most influential theories, and the final three sections will suggest an alternative.

\section{Hezekiah's Delayed Passover in 2 Chronicles 30}

Building on the fact that, according to 2 Chronicles 30, King Hezekiah must consult with the city elite to hold a belated Passover rather than draw on Mosaic authority, Ehrlich inferred that the law of the Second Passover in Num 9:1-14 originated in

\footnotetext{
${ }^{6}$ What is more, note the way the form of Num 9:1-2 seems to parallel Exod 12:2-3, which suggests deliberate modeling:

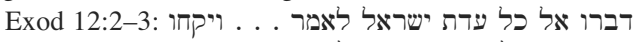

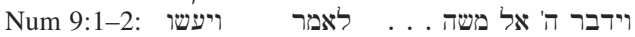

${ }^{7}$ See Michael Fishbane, Biblical Interpretation in Ancient Israel (2d ed.; Oxford: Clarendon, 1986; repr. 1989) 98-106.

${ }^{8}$ For example, Wilhelm M. L. de Wette, Lehrbuch der historisch-kritischen Einleitung in die kanonischen und apokryphischen Bücher des Alten Testamentes (6th rev. ed.; Berlin: Reimer, 1845) 203-8 (\$\$152-153); Samuel R. Driver, Introduction to the Literature of the Old Testament (7th ed., 1898; repr. Cleveland: Meridian, 1963) 159; Martin Noth, A History of Pentateuchal Traditions (trans. B. W. Anderson; Germ. orig. 1948; Englewood Cliffs, New Jersey: Prentice-Hall, Inc., 1972) 261-76, esp. 272, 273, 275; Israel Knohl, The Sanctuary of Silence: The Priestly Torah and the Holiness School (trans. J. Feldman and P. Rodman; Minneapolis: Augsburg Fortress, 1995) 105 and passim.

${ }^{9}$ For some arguments that the law first existed without the narrative altogether, see Heinrich Holzinger, Numeri (KHAT; Tübingen-Leipzig: Mohr-Siebeck, 1903) 35; Diether Kellerman, Der Priesterschrift von Numeri 1:1 bis 10:10 (BZAW; Berlin: Walter de Gruyter, 1970) 129-32; Jacob Licht, A Commentary on the Book of Numbers (3 vols.; Jerusalem: Magnes, 1985-1995) 1:135, 138-39 [Hebrew]; Knohl, ibid., 90.
} 
the wake of Hezekiah's deferred Passover. ${ }^{10}$ Chronicles, by implication, preserves an ancient historical memory. Nearly sixty years later (without referring to Ehrlich), Shemaryahu Talmon proposed a more ambitious version of this suggestion. To his mind, Jeroboam I's festival in the eighth month, related in $1 \mathrm{Kgs} 12: 32-33$, together with Hezekiah's Passover in the second month, reflect a northern, Israelian ${ }^{11}$ agricultural cycle and corresponding calendar that differ from those in Judah in the south, lagging behind them by a month. The Second Passover instituted in Num 9:1-14 represents Hezekiah's politically motivated attempt at incorporating the northern Israelian calendar into that of the Judahite south. ${ }^{12}$

The Hebrew Bible does attest to original laws earning Mosaic authority only secondarily. ${ }^{13}$ Calendars, for that matter, are indeed notorious for their political significance - as the story of Jeroboam I's change in 1 Kgs 12:26-33 makes deliberately unmistakable. However, even granting the dubious assumption by Ehrlich and Talmon alike that Chronicles can hold so much reconstructive value for an entire historical chapter in the First Temple period, the approach with respect to this particular event has several serious flaws that thoroughly undermine its viability.

1) The assertion of a neat dichotomy between the agricultural cycles in the north and the south directly contradicts the vast agricultural data compiled anthropologically by Gustaf Dalman and mined from rabbinic literature by the botanist Yehuda Feliks; it confuses geography with topography, kingdoms with highlands and lowlands, atlas with almanac. Rather than distinguishing north from south, agricultural seasons in the land of Israel tend to differentiate the Jordan valley

${ }^{10}$ Ehrlich, Scripture in Its Plain Sense, 1:254. In Ehrlich's opinion the author of Chronicles reports an historical event but did not know the law legislated in its aftermath. Ehrlich does not go so far as to state that Numbers 9 was written after 2 Chronicles 30. For a convenient list of Pentateuchal references found in the book of Chronicles, see Judson R. Shaver, Torah and the Chronicler's History Work: An Inquiry into the Chronicler's References to Laws, Festivals, and Cultic Institutions in Relationship to Pentateuchal Legislation (Atlanta: Scholars, 1989) 73-121. On the nature of such references (for example, 2 Chr 30:15-16, 18), see the important discussion in Sara Japhet, The Ideology of the Book of Chronicles and Its Place in Biblical Thought (trans. A. Barber; 2d rev. ed.; Frankfurt am Main: Lang, 1997) 234-44, esp. 239-44.

${ }^{11}$ H. L. Ginsberg's aptly coined term in his work, The Israelian Heritage of Judaism (New York: The Jewish Theological Seminary of America, 1982) 1-2.

12 Shemaryahu Talmon, "Divergencies in Calendar-Reckoning in Ephraim and Judah," VT 8 (1958) 48-74; reprinted as "The Cult and Calendar Reform of Jeroboam I," in idem, King, Cult and Calendar in Ancient Israel: Collected Studies (Jerusalem: Magnes, 1986) 113-39.

${ }^{13}$ See, for example, Isac Leo Seeligmann, Studies in Biblical Literature (ed. A. Hurvitz et al.; Jerusalem: Magnes, 199) 11-45, at 37-39 (Hebrew; German translation: idem, Gesammelte Studien zur Hebräischen Bibel [ed. E. Blum; FAT 41; Tübingen: Mohr Siebeck, 2004] 77-118); also Fishbane, Biblical Interpretation in Ancient Israel, 256-61, 530-34. 
from the hills and the coastal plains. ${ }^{14}$ Accordingly, the supposition of two competing fixed calendars emerges as overly speculative and essentially unusable. ${ }^{15}$

2) In addition to the problems with the above synthesis, building it upon the text of 2 Chronicles 30 as if it represents a reliable historical source encounters several significant obstacles. ${ }^{16}$ First of all, one can discern no base-text with which to bridge the roughly four centuries between the composition of Chronicles and the events it describes. Hezekiah's Passover has no parallel material anywhere. ${ }^{17}$ Likewise, from the very first phrases of the chapter, שלח על כ"sent to") and (") ("wrote letters to"), to the episode's finale in an inconsistent concatenation of clauses culminating in the distinctive syntax of Hezekiah's prayer, the language represents not a classical biblical Hebrew base overlaid by the Late Biblical Hebrew of Chronicles, but rather a stratum fundamentally and consistently late in character, which makes the idea of any pre-existing base-text or orally transmitted memories tendentious in the extreme. ${ }^{18}$

Secondly, the backbone of the plot of Hezekiah's Passover, namely, the relationship he forges with the northern populace, appears highly suspect against

${ }^{14}$ Gustaf Dalman, Arbeit und Sitte in Palästina (7 vols., 1928-1942; repr., Hildesheim: Georg Olms, 1964) 2:215-18; 3:1-6; Yehuda Feliks, Agriculture in Eretz-Israel in the Period of the Bible and Talmud: Basic Farming Methods and Implements (2d rev. ed.; Jerusalem: Rubin Mass, 1990) 173-88, esp. 175-79 [Hebrew].

${ }^{15}$ See John Gray, I \& II Kings: A Commentary (OTL; London: SCM, 1964) 292-93; Ginsberg, The Israelian Heritage of Judaism, 59. On this specific point, see also the criticisms in Oded Borowski, Agriculture in Iron Age Israel (Winona Lake, Ind.: Eisenbrauns, 1987) 41-42.

${ }^{16}$ For a balanced illustration of how to mine Chronicles for historical data, see Gary Knoppers, "History and Historiography: The Royal Reforms," in The Chronicler as Historian (ed. M. Patrick Graham et al.; JSOTSup 238; Sheffield: Sheffield Academic Press, 1997) 178-203. For a critical survey of the history of scholarly positions on the reliability of Chronicles, see Kai Peltonen, History Debated: The Historical Reliability of Chronicles in Pre-Critical and Critical Research (2 vols.; Helsinki: The Finnish Exegetical Society, 1996).

${ }^{17}$ See, for instance, the lists of correspondences in de Wette, Lehrbuch der historisch-kritischen Einleitung, 241-42; Abba Bendavid, Parallels in the Bible (Jerusalem: Carta, 1972) 141-42, more broadly, 140-44, 156 [Hebrew]; of particular significance, Robert Polzin, Late Biblical Hebrew: Toward an Historical Typology of Biblical Hebrew Prose (Missoula, Mont.: Scholars, 1976) 27-28; also, John C. Endres et al., Chronicles and Its Synoptic Parallels in Samuel, Kings, and Related Biblical Texts (Collegeville, Minn.: The Liturgical Press, 1998) 209-306, esp. 300 (the graph), 303-5. From 2 Chronicles 29 to the end of the book in chapter 35, the ratio between material revised from the book of Kings and unparalleled material radically changes from that in the rest of Chronicles, which makes the historicity of this section highly dubious. Note well how Steven McKenzie's study The Chronicler's Use of the Deuteronomistic History (HSM; Atlanta: Scholars, 1984) stops at 2 Chronicles 28.

${ }^{18}$ For several relevant telltale signs of Late Biblical Hebrew, see Eduard Y. Kutscher, The Language and Linguistic Background of the Isaiah Scroll (Jerusalem: Magnes, 1959) esp. 266-74, 305-14, 340-42 [Hebrew]; Jan Joosten, "The Distinction Between Classical and Late Biblical Hebrew as Reflected in Syntax," Hebrew Studies 46 (2005) 327-39 and bibliography; with respect specifically to Chronicles, Polzin, ibid., 28-84 (but regarding the placement of numerals, qualify by Steven Weitzman, "The Shifting Syntax of Numerals in Biblical Hebrew: A Reassessment," JNES 55 [1996] 177-85). 
the archaeological and epigraphical data. Finds indicate that as part of the expulsion of the Israelian populace, Sargon II repopulated the north with foreign elements in successive waves and maintained it actively and intensively. ${ }^{19}$ Hezekiah's calling upon the northern populace, even only those Israelians that remained, to celebrate a national festival in the competing capital of Jerusalem would mount a direct, open challenge to Assyrian hegemony. In light of the repeated Assyrian incursions and major successes in the region, the image of Hezekiah, at an early stage of his reign, reaching out to poke a Judean thumb in the Assyrian eye seems difficult to envision. $^{20}$

Indeed, one can fully account for the existence of the story of Hezekiah's Passover on hermeneutical grounds alone. ${ }^{21}$

3) Moving from the historical unreliability of the account in 2 Chronicles 30 to underlying phenomenological suppositions, the view of Ehrlich and Talmon that the supplementary Second Passover in Numbers 9 reflects Hezekiah's delayed Passover in 2 Chronicles 30 assumes that the two texts refer to one and the same phenomenon. However, a careful comparison of Numbers 9 and 2 Chronicles 30 shows that this view involves misleading abstractions that overlook defining details. The analysis below will demonstrate that the two texts describe two completely different and unrelated phenomena; that, accordingly, the texts employ alternate sets of terms; and that, undergirding the distinction, the texts are in total accord with their respective textual environments - namely, the Priestly literature and

${ }^{19}$ Nadav Na'aman and Ran Zadok, "Sargon II's Deportations to Israel and Philistia (716-708 B.C.)," JCS 40 (1988) 37-46; David P. Wright, "The Laws of Hammurabi as a Source for the Covenant Collection (Exodus 20:23-23:19)," Maarav 10 (2003) 11-87, at 58-67; J. Maxwell Miller and John H. Hayes, A History of Israel and Judah (2d ed.; Louisville, Ky.: Westminster John Knox, 2006) 388-90, 403-10.

${ }^{20}$ Nadav Na'aman, “The Debated Historicity of Hezekiah's Reform in the Light of Historical and Archaeological Research," ZAW 107 (1995) 179-95, at 180-81. Hezekiah's rebellion against Sargon II's son Sennacherib (2 Kgs 18:17-19:37) would represent a change in policy meant to take advantage of the opportunity provided by the death of the previous king, during the instability presumably occasioned by it, not evidence of an ongoing struggle emerging now in full-blown proportions. Compare Miller and Hayes, ibid., 410-20, who reapply this "northern initiative" in 2 Chronicles 30 to preparations for war in the wake of Sargon's death. But they couple this move with Hezekiah's centralization of the cult more broadly, which raises more problems than it solves. For further remarks on the problems in taking the story as historical, see Fishbane, Biblical Interpretation in Ancient Israel, 155.

${ }^{21}$ The point will have to appear elsewhere, but the hermeneutical touchstones comprise 1) the apparent contradiction between $2 \mathrm{Kgs}$ 18:5 and $2 \mathrm{Kgs}$ 23:25 and the historical questions raised by them; 2) Hezekiah's unique opportunity to undo the damage wrought by Jeroboam I and return to the glorious days of Solomon; and 3) the role of the Levites in the Passover in Ezra 6:20 (see also 2 Chr 35:2-6, 10-14). On Chronicles' Hezekiah as a second Solomon, see Andrew G. Vaughn, Theology, History, and Archaeology in the Chronicler's Account of Hezekiah (Atlanta: Scholars, 1999) 174-79. On the reunification of Israel and Judah as a constitutive ideological plank in Chronicles, see Japhet, The Ideology of the Book of Chronicles, 267-334. 
Chronicles - and never so much as refer to one another. Any apparent points of contact claimed to exist between the two texts evaporate as illusory. ${ }^{22}$

The passage about the Second Passover in Numbers 9 establishes a precedent and enacts a permanent law. This new law targets only the individual. Taken at face value, the law implies that because missing the Passover leads to the severe result of כרת (being “cut off”), it provides for those unable to attend because circumstances beyond their reasonable control had them impure or too far away during the Passover's primary date. ${ }^{23}$ The dispensation covers only the Passover sacrifice itself; the Festival of Unleavened Bread remains firmly anchored to the first month. As a result, the celebrant comes with, at the most, just his own immediate family. These facts are so clear as to have generated a midrashic-style digression within the text itself on the practical implications a Passover held a month late would have on the Passover laws (vv. 11b-12): ${ }^{24}$ Disconnected from the Festival of Unleavened Bread, shall the pilgrim eat the Passover without unleavened bread (and bitter herbs)? In the absence of enough people to consume all the meat, can the leftovers be eaten the next day? Perhaps only some of the animal need be prepared, not all of it? The passage answers: all laws remain in force regardless of the artificial circumstances. ${ }^{25}$

The circumstances of Hezekiah's Passover in 2 Chronicles 30 could not differ more. Hezekiah defers the Passover not on the basis of any law or tradition, but solely and explicitly through human deliberation and consultation capped by his own royal decree. He does so as a limited, one-time decision in response to very specific circumstances (note the palpable relief with which the author stresses that the circumstances did not recur in the Passover of the returnees, in Ezra 6:19-20). These circumstances, moreover, have nothing to do with the ritual or physical ability of any individual to attend the Passover, but rather reflect the larger socio-political interests of the king, the lethargy of the priests and the apathy of the people. Hezekiah pushes off the Passover in its entirety, together with the Festival of Unleavened Bread, even for those who did come to Jerusalem to celebrate the first time around (2 Chr 30:21-22). The priests were not prevented by "impurity" but rather unmotivated

${ }^{22}$ In this vein, note Ehrlich's remark: "The author of Chronicles did not know the laws of the Second Passover; otherwise, he would have said of Hezekiah's Passover that it was done in accordance with the Torah" (Scripture in Its Plain Sense, 1:254). The citation in $2 \mathrm{Chr} 30: 18$ could refer to the implicit assumption in Num 9:6, 7, 10-11, but much more likely, it points to the explicit prohibition in Lev 7:19-20.

${ }^{23}$ For a discussion of the Priestly concept of guilt that has implications for the concept of כרת, see Baruch J. Schwartz, "The Bearing of Sin in the Priestly Literature," in Pomegranates and Golden Bells: Studies in Biblical, Jewish, and Near Eastern Ritual, Law, and Literature in Honor of Jacob Milgrom (ed. D. P. Wright et al.; Winona Lake, Ind.: Eisenbrauns, 1995) 3-21, esp. 8-14.

${ }^{24}$ See m. Pesah. 9:3; t. Pesah. 8:7; Sipre $\$ 69$.

${ }^{25}$ While answering these questions, the laws in vv. $11 \mathrm{~b}-12$ also improve the formulation of the original laws in Exod 12:8-10. Literary-critical indications suggest that these three elements represent a secondary expansion, and also, against consensus opinion, that Exod 12:46 then borrowed from and revised Num 9:12. 
to "sanctify themselves" (v. 3); ${ }^{26}$ indeed, subsequently in the story, impurity prevents no one from participating in the Passover: Hezekiah's prayer suffices to cover them (vv. 17-20). ${ }^{27}$ Likewise, the people who did not come to Jerusalem for Hezekiah's original Passover were not unable to do so but simply uninterested in doing so (vv. 3-12). The threat of כרת never even enters the debate. ${ }^{28}$

The one apparent link, the close linguistic similarity between the phrase "because they could not perform it at that time" in $2 \mathrm{Chr} 30: 3$ and that in the narrative passage Num 9:6, "and they could not perform the Passover on that day," in fact offers a parade example of an exception that proves the rule. ${ }^{29}$ In Numbers 9, the clause refers to those who were prevented from coming to perform the Passover altogether, whereas in 2 Chronicles 30 it describes that minority that did arrive for the Passover, but was prevented from observing it because of the majority that did not show up or sanctify themselves. As said above, in Numbers 9, only those prevented from participating perform the Passover subsequently; in 2 Chronicles 30, Hezekiah defers the Passover equally for everyone, as the text declares explicitly: "The king

${ }^{26}$ Note that the phrase, which appears to suggest a relative state rather than the absolute one of impurity, almost always applies to the priests and Levites alone (1 Chr 15:12, 14; 2 Chr 5:11; 29:5, 15,$34 ; 30: 3,15,24 ; 31: 18 ; 35: 6$; contrast only 30:17).

${ }^{27}$ On the basis of 2 Chr 30:6-9, 14; 31:1, it seems safe to conclude further that the Chronicler meant to indicate that the impurity contracted by these Israelites have contracted derives not from a corpse but from idolatry; so Fishbane, Biblical Interpretation in Ancient Israel, 154, 156, 249. On impurity caused by idolatry, see, for example, Lev 18:21, 24-30; 19:31; 20:1-7; Jer 2:23; Ezek 20:7, 18, 27-31, 43; 22:3-4; 36:18; 37:23; Ps 106:34-40. On its character see Jonathan Klawans, Impurity and Sin in Ancient Judaism (Oxford: Oxford University Press, 2000) 26-31.

${ }^{28}$ This comprehensive set of essential differences between the Second Passover of Numbers 9 and Hezekiah's deferred holiday precludes the opposite contention as well, that the story in 2 Chronicles 30 represents the extension and application of the law in Numbers 9, as Fishbane would have it (Biblical Interpretation in Ancient Israel, 154-59, 248-49). Indeed, had the author of 2 Chronicles 30 in fact derived the deferred Passover he described from the Second Passover in Numbers 9 , he would have drawn upon such Pentateuchal authority explicitly, as so often occurs precisely in these kinds of legal midrash throughout Chronicles (see above, n. 10). As said already above (n. 22), it is just this reasoning that led Ehrlich to suggest that the law in Numbers 9 emerged in the wake of Hezekiah's Passover as described in 2 Chronicles 30: why have Hezekiah "consult" with local leaders if he could rest on such a pillar as Mosaic authority by citing a Pentateuchal passage (Scripture in Its Plain Sense, 1:254)? The differences analyzed above suggest that the author of the story in 2 Chronicles 30 did not cite from or even refer to the law in Numbers 9 because he saw them as two distinct phenomena, analogous perhaps, but with no actual points of contact between them to warrant drawing a direct connection. As Fishbane's study illustrates so trenchantly, exegesis leaves a trail; in this case, though, no signs of it exist. And one cannot use the analogy between the texts as an indication of exegesis, for it is the presence and nature of just this analogy that is under debate.

${ }^{29}$ Contra Fishbane, ibid. The text is my translation; see the even more pronounced similarity in the Hebrew original:

ולא יכלו לעשות הפסח ביום ההוא

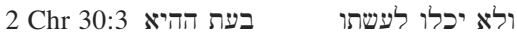


and his officers and the congregation in Jerusalem had to keep the Passover in the second month, for at that time they were unable to keep it." 30

Seen in this light, the phenomenon described in 2 Chronicles 30 recalls the well-known one-time manipulations in the Greek calendar similarly effected for various political, military and social reasons. In these cases, a month is called by the name of the previous month, or specific dates are moved backwards or frozen to repeat themselves for extended numbers of days. ${ }^{31}$ For instance, in order to placate his soldiers and sidestep a tradition against fighting in a particular month, Alexander the Great changed the name of the month to that of the previous one. In the campaign against Tyre he changed the date within the month from the 30th to the 28 th to make a prophecy of victory that month more credible - and inspiring - to his soldiers. ${ }^{32}$ Thucydides recounts that in order to avoid a ban on fighting in a sacred month, the Argives counted the 27th of the preceding month for the duration of their campaign. ${ }^{33}$ Similarly, when the Athenians needed to delay the festival of Dionysos, they did so by repeating the date prior to that of the festival for four days in a row. ${ }^{34}$ In an extreme instance, Demetrius wrought havoc on the months in the Athenian calendar in order to have himself initiated into all the mysteries at once, rather than over a period of more than a year and a half..$^{35}$ These examples culled from the fifth, fourth, and third centuries B.C.E. match the period of the composition of Chronicles. ${ }^{36}$ The rabbis referred precisely to this practice when they censured Hezekiah for intercalating the month of Nissan within Nissan itself, turning Nissan into a repeated Adar, in order to defer the Passover. ${ }^{37}$

To put it more succinctly, the law of the Second Passover in Num 9:1-14 has no impact on the calendar itself and describes rather a personal "make-up" date for the individual pilgrim. In stark contrast, the story of Hezekiah's Passover in 2

${ }^{30}$ Italics mine.

${ }^{31}$ On the phenomenon, see Simon Price, Religions of the Ancient Greeks (Cambridge: Cambridge University Press, 1999) 25-29. Thanks to Amram Tropper for pointing me to this discussion.

${ }^{32}$ Plutarch's Lives (vol. 7; Loeb Classical Library; Cambridge, Mass.: Harvard University Press, 1919; repr., 1967), “Alexander,” ch. 16 §1-2, pp. 263-65; chap. 25 §1-2, pp. 295-97.

${ }^{33}$ Thucydides, The Peloponnesian War (vol. 3; Loeb Classical Library; Cambridge, Mass.: Harvard University Press, 1921; repr., 1966) book 5 §53-54, pp. 105-7.

${ }^{34}$ Arthur Pickard-Cambridge, The Dramatic Festivals of Athens (rev. J. Gould and D. M. Lewis; 2d ed.; Oxford: Clarendon, 1968) 65.

${ }^{35}$ Plutarch's Lives (vol. 9; Loeb Classical Library; Cambridge, Mass.: Harvard University Press, 1920; repr., 1968), "Demetrius," ch. 26 \$1-3, pp. 61-63.

${ }^{36}$ For additional examples, but without their historical contexts, see Benjamin D. Meritt, The Athenian Year (Berkeley: University of California Press, 1961) 161-65.

${ }^{37}$ See $m$. Pesah. 4:9; b. Pesah. 56a. More stringently, recall the Hittite law cited above: "You who (are) temple officials: If you do not perform the festivals at the time of the festivals; (if) you do the spring festival in fall, (or) the fall festival in spring" (The Context of Scripture, 1:219 \$9). Against this background, it seems quite plausible to see in a similar light the month "dreamt up"

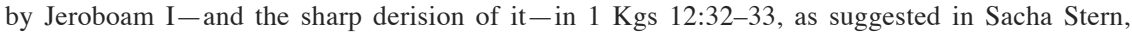
Calendar and Community: A History of the Jewish Calendar, Second Century BCE-Tenth Century CE (Oxford: Oxford University Press, 2001) 2-3. 
Chronicles 30 tells of an intervention in the calendar that affects everyone equally and from the very outset was intended to do so. The Passover, together with the Festival of Unleavened Bread, takes place on its correct, original date, on the fourteenth of the first month, but that date has been deferred for nearly thirty days by the addition of a month. From this point of view, one should not be misled by the use of the term שני that modifies the "month" in which they perform the Passover (vv. 2, 13, 15). In Numbers 9, the term means "second," as it does everywhere else in calendar references within the Priestly literature. In light of the above, though, in 2 Chronicles 30, it must mean "other, next." 38 The two texts, then, describe two fundamentally different phenomena unlinked by any relationship, historical, analogical or other. ${ }^{39}$

One final point remains to be made. Ehrlich and Talmon do not take into account the two provisions explicitly established by the law, namely, that one may miss or defer the Passover if he contracted impurity beforehand or found himself too far away. Methodologically speaking, any theory about the Second Passover should first attempt to anchor itself in at least one of these two provisions.

\section{Yehud, the Merchant Community}

In 1903, Heinrich Holzinger articulated what has remained the most widely held opinion on the matter today:

The law very obviously presumes the circumstances of the post-exilic period, when the Jews became a merchant community, who frequently found themselves on business trips. ${ }^{40}$

This explanation clearly puts decisive emphasis on the provision of distance. Moreover, it is critical to appreciate that Holzinger does not infer a relative rise in the number of people traveling within the local markets of Yehud to supplement their resources by bartering or otherwise exchanging their excess produce for other necessities. Rather, he posits a fundamental change in the very nature of the society in Yehud, from that of subsistence farmers into a community of longdistance traders. ${ }^{41}$

${ }^{38}$ Abū al-Walīd (Jonah) Ibn Janāḥ, Sefer Hashorashim (ed. W. Bacher; trans. J. Ibn Tibbon; Berlin, 1896; repr. Jerusalem, 1966) 524-25 [Hebrew]; Ludwig Koehler and Walter Baumgartner, The Hebrew and Aramaic Lexicon of the Old Testament: Study Edition (trans. and ed. M. E. J. Richardson; rev. W. Baumgartner and J. J. Stamm; 2 vols.; Leiden: Brill, 2001) 2:1604-5.

39 See also Segal, The Hebrew Passover, 200 n. 7, 229; Sara Japhet, I \& II Chronicles: A Commentary (OTL; London: SCM, 1993) 939-40.

${ }^{40}$ Holzinger, Numeri, 35.

${ }^{41}$ Similarly, for instance, Philip J. King and Lawrence E. Stager, Life in Biblical Israel (Louisville, Ky.: Westminster John Knox, 2001) 193-94. In this spirit, note the following remark on the implementation of monotheism in the Return period:

[T] he differentiation between truth and reality, operational as it is in the distinction of gods and a true God, presuppose (sic!) most probably the mind's acculturation to a monetarian economy in which every thing has a value measured and attributed different 
Such a radical transformation in the basic structure of a society should leave its imprint on the literature or archaeological record of its time. Yet the scholars espousing the theory of just such a transformation have yet to cite any evidence to support it, biblical or archaeological. To the contrary, the Priestly literature to which the passage of the Second Passover in Num 9:1-14 belongs consistently depicts a provincial, patriarchal, agrarian Israel - in the history it writes for retelling, in the laws it legislates for practice, as well as in its underlying theology and ideology. ${ }^{42}$ Indeed, David Margoliouth's comprehensive and nuanced survey in 1939 reveals that the Hebrew Bible as a whole, a large portion of which comes from the period of the return in the sixth and fifth centuries B.C.E., rarely refers to trade, and when it does, it directs itself to the uppermost crust of society, either explicitly or by referring to high-end luxury goods - hardly the reflection of a society broadly and fundamentally engaged in long-range, large-scale trade. ${ }^{43}$ Margoliouth's findings lead him to conclude further, "it would appear that till the taking of Jerusalem by Titus, and perhaps even later, agriculture remained the normal occupation of the Israelites." 44

From the standpoint of archaeology, material finds from the period of the return do not indicate the sharp increase in the kinds, amounts, and origins of goods befitting a community gone suddenly from farmer to merchant. Rather, initially, they continue First Temple patterns; subsequent growth and change remain moderate and gradual. Surveys, for that matter, have yet to turn up the sizable warehousing depots, distribution centers, and markets appropriate to large-scale, long-distance trade. ${ }^{45}$ To the contrary, settlement patterns reflect decentralized, rural farming

from its inherent (natural) virtues (e.g., to feed, warm, or protect). So, monotheism might have indeed originated in Jerusalem (or, previously or simultaneously, in the Babylonian support group of the settlers of the Persian period).

Ernst A. Knauf, review of Othmar Keel, Die Geschichte Jerusalems und die Entstehung des Monotheismus (Göttingen: Vandenhoeck \& Ruprecht, 2007), RBL 05/2008, n.p. [cited 16 June 2008]; online: http://www.bookreviews.org/pdf/6377_6859.pdf.

${ }^{42}$ Along these lines, see Jan Joosten, People and Land in the Holiness Code: An Exegetical Study of the Ideational Framework of the Law in Leviticus 17-26 (SVT 67; Leiden: Brill, 1996); Jacob Milgrom, Leviticus (3 vols.; AB; New York: Doubleday, 1991-2001) 2:1352-57, 1391-93, 1397-1404, 1407-14.

${ }^{43}$ David S. Margoliouth, "Trade and Commerce," in James Hastings' Dictionary of the Bible (New York: Charles Scribner's Sons, 1939) 944-46. Analysis of commercial terms and consciousness in Qohelet exemplifies the point well; see James L. Kugel, "Qohelet and Money," CBQ 51 (1989) 32-49, at 45-49, esp. 46.

${ }^{44}$ Margoliouth, "Trace and Commerce," 946.

${ }^{45}$ See Ephraim Stern, "The Archaeology of Persian Palestine," in The Persian Period (ed. W. D Davies and L. Finkelstein; vol. 1 of The Cambridge History of Judaism; Cambridge: Cambridge University Press, 1984) 88-114. The granaries found in Palestine, reflecting the Persian military system (ibid., 113), have been linked to regional trade by which the Persians intended to strengthen Yehud and the entire western frontier; see Charles E. Carter, "The Province of Yehud in the PostExilic Period: Soundings in Site Distribution and Demography," in Temple Community in the Persian Period (ed. T. C. Eskenazi and K. H. Richards; vol. 2 in Second Temple Studies; Sheffield: Sheffield Academic Press, 1994) 106-45, esp. 139-45. 
communities. ${ }^{46}$ Moreover, Yehud itself may have been too small and too poor to produce enough to survive, let alone thrive, as a merchant community. ${ }^{47}$

Historically speaking, the constant external pressure seemingly exerted by other local groups and the concomitant power vacuum that characterized the period at least until the latter part of the fifth century B.C.E. (see Nehemiah 1-4,6) make it hard to imagine the Jewish community successfully establishing and maintaining the infrastructure necessary for constant large-scale travel, shipping, and distribution. The beleaguered returnees struggled even to rebuild the one temple in Jerusalem. Again, the archaeological record strongly suggests that Yehud did not even begin to recover from the wholesale destruction caused by the Babylonians and emerge recognizably as a state until the latter part of the Persian period, in the late fifth and fourth centuries B.C.E. ${ }^{48}$ Jerusalem itself remained extremely small, its population never expanding beyond the spur known as the city of David until the Hellenistic period. ${ }^{49}$

A spate of studies from the 1990s strongly discounts the viability of the merchantcommunity model for Yehud. Jack Pastor's socio-economic study of the Second Temple period highlights subsistence farming as the backbone of the economy. ${ }^{50}$ The various data brought by Yaron Dan for the period turn the tables on the merchant community conception to depict Yehud more as a hub or way-station for foreign merchant communities, particularly Phoenician merchants promoted by Persian interests and backing. ${ }^{51}$ Ze'ev Safrai's study of Roman Palestine, reaching back to the Persian period, meets the theory head on and rejects it outright as entirely unfounded and contradicted by the literary evidence not only in the Talmud, but in non-Jewish sources as well. ${ }^{52}$

${ }^{46}$ Kenneth Hoglund, "The Material Culture of the Persian Period and the Sociology of the Second Temple Period," in Studies in Politics, Class and Material Culture (ed. P. R. Davies and J. M. Halligan; vol. 3 of Second Temple Studies; Sheffield: Sheffield Academic Press, 2002) 14-18, at 18.

${ }^{47}$ Carter, "The Province of Yehud in the Post-Exilic Period."

${ }^{48}$ Ephraim Stern, The Assyrian, Babylonian, and Persian Periods (732-332 B.C.E.) (vol. 2 of Archaeology of the Land of the Bible; New York: Doubleday, 2001) 307-11, 323-26, 348-50, 576-82.

${ }^{49}$ Ibid., 434-36.

${ }^{50}$ Jack Pastor, Land and Economy in Ancient Palestine (London: Routledge, 1997) 1-20, 168-70.

${ }^{51}$ Yaron Dan, "Trade within and Trade without the Land of Israel in Second Temple Times," in Chapters in the History of Trade in the Land of Israel (ed. B. Kedar et al.; Jerusalem: Yad Ben-Zvi and the Israel Exploration Society, 1990) 91-107 [Hebrew]; see further Ephraim Stern, "Between Persia and Greece: Trade, Administration and Warfare in the Persian and Hellenistic Periods," in The Archaeology of Society in the Holy Land (ed. T. E. Levy; London: Leicester University Press, 1995) 432-45; idem, The Assyrian, Babylonian, and Persian Periods, 379-422, 559-61. Jacob L. Wright adds that in Neh 13:15-22, "Nehemiah's Memoir" ascribes the activity of long-distance trade to Phoenicians, not Yehudim (personal communication).

${ }^{52}$ Ze'ev Safrai, The Economy of Roman Palestine (London: Routledge, 1994) 222-414, esp. $315-16$. 
Finally, the foregoing concrete considerations benefit from the strength of theoretical support. The very idea of a pre-industrial merchant society, in which large numbers of members regularly travel abroad to distant lands and live primarily by trade, simply does not fit with current models in sociological research. Large-scale, long-distance trade remains in the hands of the wealthiest few, while the average citizen struggles to eke out a subsistence living through agriculture, whether as owner or otherwise. ${ }^{53}$ With regard to ancient Israel in particular, Magen Broshi made several important methodological remarks, pointing out that the incredibly high costs of long-distance transportation and distribution, coupled with the fact that the majority of goods transported and distributed throughout the ancient world comprised non-produce, luxury items, deny the likelihood of a Jewish merchant community engaged in large-scale commerce. ${ }^{54}$ Likewise, Richard Horsley reveals such models as anachronistic, having more to do with Western socio-economic history than ancient Near Eastern. ${ }^{55}$

Taken together, all these literary, archaeological, historical, and sociological analyses uniformly paint in bold strokes a completely different picture of the returnees than that posited by Holzinger and others. The economic structure of life for Israelians and Judahites in the Iron Age did not undergo fundamental change for Jews in the Persian period (and beyond): as a community, the majority of Jews lived first and foremost not by long-distance, large-scale trade, but rather by subsistence agriculture, supplementing their material needs through local markets. ${ }^{56}$

The conception here bankrupted does have one very significant merit, the recognition that one should look only to the terms of the law itself in order to reconstruct its origins and not rely on the narrative currently attending it. The law of the Second Passover delineates only two scenarios as warranting a make-up sacrifice - impurity and distance. The story of the legislation of the Second Passover, though, tells only of a case of impurity. As noted at the outset, scholarship has not taken the story prima facie as historical, but the story, by its very presence, can create the impression that it has value for the historical reconstruction of the law. Specifically, it can suggest that at the heart of the law lies impurity, whereas

${ }^{53}$ The classic work on the topic is Moses I. Finley, The Ancient Economy (3rd ed.; Berkeley: University of California Press, 1999); see also Karl Polanyi, The Livelihood of Man (ed. H. W. Pearson; New York: Academic Press, 1977). For a collection of essays qualifying Finley's views, see Economies beyond Agriculture in the Classical World (ed. D. J. Mattingly and J. Salmon; London: Routledge, 2001), esp. 3-11, a nuanced overview of the significance of the volume for Finley's theories.

${ }^{54}$ Magen Broshi, "On Trade in Ancient Times: Some Methodological Notes," in Chapters in the History of Trade in the Land of Israel, 195-201 [Hebrew].

${ }^{55}$ Richard A. Horsley, "Empire, Temple and Community - but No Bourgeoisie! A Response to Blenkinsopp and Peterson," in Persian Period (ed. P. R. Davies; vol. 1 of Second Temple Studies; Sheffield: Sheffield Academic Press, 1991) 163-74.

${ }^{56}$ See also J. David Schloen, The House of the Father as Fact and Symbol: Patrimonialism in Ugarit and the Ancient Near East (Studies in the Archaeology and History of the Levant 2; Winona Lake, Ind.: Eisenbrauns, 2001) 83-89, 101-4, 140-41 and passim. 
distance constitutes a second-order clause, or even, some scholars go so far as to infer, a secondary one. ${ }^{57}$

However, it is the larger narrative context of the wilderness that has determined the case related in the story. For the law to emerge from a case of distance simply would not suit the wilderness context, when according to the presuppositions of the larger narrative history, the Israelites are always within walking range of the tabernacle. Impurity, by contrast, can occur in any place at any time as the byproduct of any normal death and render someone unfit to approach the tabernacle. In response to precisely this incongruity between the law's provision of distance and the larger wilderness context, Ibn Ezra parsed the unusual phrase in v. 10 "of you or of your posterity" (לכם או לדרתיכם) as follows (ad loc.):

"of you"-with reference to the impure person; "or of your posterity" - with reference to either the impure person or the person too far away.

To take his insight one critical step further, this uncharacteristic qualifier itself appears to represent an interpolation designed specifically to bridge this very gap between the law's provision for distance and its complete irrelevance to the narrative context. ${ }^{58}$ In order to set the origins of the Second Passover law within the wilderness context, the story had to describe a case of impurity. This means that to reconstruct the origins of the law of the Second Passover, one should resist the misimpression created by the story that the weight of the law falls on impurity and consider the provision of distance as of at least equal significance. ${ }^{59}$

\section{Centralization and Distance}

What circumstances, then, might lie behind the concept of "distance"? In what historical context would a problem of proximity have led to the legislation of the Second Passover? The answer hinges on the meaning of "distance." For those who would have the law referring to an Israelite away on a journey, "distance" refers to

${ }^{57}$ See Baentsch, Exodus-Leviticus-Numeri, 492; also Fishbane, Biblical Interpretation in Ancient Israel, 103; from a different point of view, Alexandser Rofé, Introduction to Deuteronomy: Part I and Further Chapters (expanded ed; Jerusalem: Academon, 1988) 14-18, at 17 [Hebrew].

The conjunction "or" can often serve as a hook by which to add material into an existing text (examples and discussion in Fishbane, ibid., 170-72), but this does mean that it must do so in every casuistic law; the prime impetus for arguing as much in this case ultimately comes from the imbalance created by the story, which throws all its weight behind the issue of impurity.

${ }^{58}$ In addition to the unique form of this clause, which otherwise appears only as "for your/their descendants" (לדרתם/לדרתיכם), note its absence in the similar casuistic laws in the parallel pericopes in Lev 24:10-23, Num 27:1-11, and 36:8-9. The fact that, as opposed to Lev 24:10-23, Num 27:1-11, and 36:1-13 (also Num 15:32-36), the passage in Num 9:1-14 does not have a mediating section in which God responds first to the actual case, then reformulates and elaborates for posterity, may exacerbate the way the legal section jars with the narrative. On the history of the term, see Avi Hurvitz, A Linguistic Survey of the Relationship between the Priestly Source and the Book of Ezekiel: A New Approach to an Old Problem (Paris: J. Gabalda, 1982) 98-101.

${ }^{59}$ Literary-critical analysis, moreover, indicates that the story represents a secondarily prepared frame intended to incorporate the law into the the larger Priestly work; see above, n. 9. 
those temporarily far away from home or homeland. However, at the literary level, the text does not necessarily warrant this interpretation, which emerges exclusively by hermeneutical analogy with the impurity clause that precedes the distance clause. The concept of "distance" may in fact have its sights set on those whose home is permanently out of reasonable range of the temple.

As amply demonstrated in the literature of the Hebrew Bible as well as in the material culture recovered by archaeology, ancient Israel of the Iron Age was a clan- and land-based agricultural society whose various structures presupposed and depended upon access to local sacred sites. The move to a single temple could wreak havoc on such structures. The Deuteronomic Code, representing the Hebrew Bible's most uncompromising call for cultic centralization, attempts to manage just such a radical transformation by anticipating (rhetorically, at the very least, if not historically) the manifold shock-waves throughout society this could cause and providing a bulwark against them through legislation. ${ }^{60}$ Palpably, the single most prevalent problem the code struggles to overcome consists of the new geographical distance opened up between individual Israelites and the single sacrificial site, namely, the inaccessibility of the temple. One can gauge the significance of distance to the program of centralization in the mind of the Deuteronomic legislators by the fact that ultimately they themselves come to employ distance as a literary trope for legal innovation. ${ }^{61}$

Explicitly, one's distance from the single legitimate sanctuary justifies local, secular slaughter (Deut 12:20-28; compare Exod 20:22-26 and Lev 17:1-7); ${ }^{62}$ exchanging tithe produce and firstborn animals for money in order then to buy fresh goods in the temple city (Deut 14:22-26); ${ }^{63}$ and the establishment of cities of asylum (Deut 19:1-10; compare Exod 21:12-14). ${ }^{64}$ Implicitly, it provides the rationale behind a host of changes in many different laws. The Hebrew slave no longer has his ear pierced in a local temple, as in Exod 21:6, but rather at the doorpost of his

${ }^{60}$ See Bernard M. Levinson, Deuteronomy and the Hermeneutics of Legal Innovation (Oxford: Oxford University Press, 1997).

${ }^{61}$ See especially Rofé, Introduction to Deuteronomy, 14-18.

${ }^{62}$ Subsequently, the passage in vv. 13-19 extended this allowance to the temple city as well.

${ }^{63}$ According to Moshe Weinfeld, the dispensation in vv. 24-26 applies to the firstborn animals mentioned alongside the tithed produce in v. 23 (Deuteronomy and the Deuteronomic School [1972; repr., Winona Lake, Ind.: Eisenbrauns, 1992] 215). In this case a contradiction emerges with 15:19-23, which requires one annually to bring to the temple all the male firstborn animals. August Knobel interpreted the provision in vv. 24-26 to apply only to the tithed produce and not to the firstborn animals (Die Bücher Numeri, Deuteronomium und Josua [KEHAT; Leipzig: Hirzel, 1861] 264-65); likewise, August Dillmann dismissed the presence of the firstborn animals in v. 23 as a tangent mentioned along with the tithe in passing because of their similarity or because they were brought to the temple at the same time (Die Bücher Numeri, Deuteronomium und Josua [2d ed.; KEHAT; Leipzig: Hirzel, 1886] 304-5).

${ }^{64}$ On the development of the cities of asylum, see Alexander Rofé, "The History of the Cities of Refuge in Biblical Law," in Studies in Bible (ed. S. Japhet; Scripta Hierosolymitana 31; Jerusalem: Magnes, 1986) 205-39, repr., idem, Deuteronomy: Issues and Interpretation, 121-47. 
master's home (Deut 15:17). ${ }^{65}$ Whereas Exod 22:28-29 required the farmer to offer every firstborn animal eight days after its birth, now the farmer may keep them all for a single annual visit to the temple; as a result, the law must stress 1) that in the costly interim, one may not give in to temptation and work them or shear them; and 2) that in light of the greater likelihood of a blemish developing, one may not bring a blemished animal, which one may as well eat at home like game (Deut 15:19-23). ${ }^{66}$ Distance from the temple also gives the law apt reason to incorporate the wisdom warning against vows, the fulfillment of which is now ever more likely to be pushed off and eventually forgotten (Deut 23:22-24; Qoh 5:3-4). With the sequestering of priestly mantic and oracular means for administering justice in the one faraway temple, the Deuteronomic law must insist upon the establishment of a local secular judiciary, determine its relationship to the centralized court, and, at the same time, thrusting in the opposite direction, assiduously assert the authority of the temple court (Deut 16:18-20 and 17:8-13; compare Exod 22:6-8). ${ }^{67}$ Likewise, in the absence of local shrines to support levitical priests and other landless or otherwise vulnerable people, the Deuteronomic law transfers that responsibility to the laity, demanding repeatedly of them that they remember these unfortunates and provide for them (Deut 12:11-12, 17-19; 14:26-29; 16:11, 14; 24:19-21; 26:12-15) ${ }^{68}$

In the specific context of the festivals, H. L. Ginsberg argued that the farmer's distance from the single temple made it imperative in D that the Harvest Festival close the harvest season (16:9-12) rather than inaugurate it, as in Exod 23:16a. By the same reasoning the Ingathering Festival must take place not after the gathering in of the harvested crops, as in Exod 23:16b, but only after their having been processed for the coming winter (Deut 16:13-15). This distance-driven adaptation had the added result of disconnecting the firstfruits from any specific date altogether; the farmer, by implication, should bring them whenever he happens to have the opportunity, recite the prayer appropriate to the occasion, and return home (Deut 26:1-11). ${ }^{69}$ Within the Priestly literature as well, Lev 23:9-22 appears to evince a change both in the omer and in the firstfruits from citizen gifts to priestly

${ }^{65}$ Samuel R. Driver, A Critical and Exegetical Commentary on Deuteronomy (3rd ed.; ICC; Edinburgh: Clark, 1902; repr., 1960) 181-85.

${ }^{66}$ Regarding vv. 20-21, see Knobel, Numeri, Deuteronomium und Josua, 268; Dillmann, Numeri, Deuteronomium und Josua, 310. The connection made here between centralization and the blemish law in vv. 21-22 seems to have escaped scholarship.

${ }^{67}$ Weinfeld, Deuteronomy and the Deuteronomic School, 233-36.

${ }^{68}$ On temple support of the local poor, see Marty E. Stevens, Temples, Tithes and Taxes: The Temple and the Economic Life of Ancient Israel (Peabody, Mass: Hendrickson, 2006) 131-35, 167-71. In the phrase "with all the desire of his soul" (בכל אות נפשו) in 18:6, Menahem Haran hears the Deuteronomic law's recognition of the difficult disconnection suffered by a Levite who leaves hearth and home to join the temple priests (Temples and Temple-Service in Ancient Israel: An Inquiry into Biblical Cult Phenomena and the Historical Setting of the Priestly School $[2 \mathrm{~d}$ ed.; Winona Lake, Ind.: Eisenbrauns, 1985; repr., 1995] 61-62, esp. 62 n. 6).

${ }^{69}$ Ginsberg, The Israelian Heritage of Judaism, 58-60. The prayer may very well have undergone a corresponding transformation from communal hymn to individual declaration. 
offerings, which effectively erases altogether the popular Pentecost, and it does this precisely for the reason that the average farmer cannot leave his fields in this critical agricultural period. ${ }^{70}$

By contrast with this list of far-reaching enactments meant to ameliorate the (envisioned) new circumstance of a distant temple, the Deuteronomic treatment of the Passover (Deut 16:1-7) achieves almost nothing. Indeed, when seen against the broad variety of adjustments made elsewhere for the sake of centralization, this text stands out for failing, or refusing, to make almost any meaningful provision at all. Rather, it remains focused almost exclusively on the demand that one perform the Passover at the one chosen sanctuary (see vv. 2, 5, 6, 7). The way the text demarcates the conclusion of the Passover as the time when one returns home resounds with the new substantial character of the journey ${ }^{71}$ - and makes the total absence of any provisions for it all the more significant: no accommodations here. ${ }^{72}$

One can recover intellectual ruminations on and responses to the impact of cultic centralization upon society not only from the Deuteronomic laws, but from rabbinic lore as well. Through a confluence of forces, the Deuteronomic idea came to define Yehud of the Second Temple period, but rabbinic materials reflecting Second Temple reality indicate that the idea of a single temple did not materialize quite the way the Deuteronomic legislators had envisioned and attempted to ensure. Shmuel Safrai's comprehensive study of rabbinic sayings, stories and legal comments about the three major pilgrimage festivals reveals that, for most of the Second Temple period, masses of people simply did not visit the place of God's choosing three times a year. Indeed, so out of step was Second Temple pilgrimage practice with the Pentateuchal pilgrimage laws that the rabbis gave those laws an otherwise bewildering reinterpretation, according to which one never need appear at the temple-except in the event that he is already in Jerusalem at the time that a festival occurs. ${ }^{73}$ The main debate as to what, geographically defined, constitutes

${ }^{70}$ Milgrom, Leviticus, 3:1981-2011, esp. 1986-87, 1991-96, 2006-7, 2009. Note that in his opinion, this change actually took place before centralization, since even a trip to a regional temple would take too much time at such an important moment in the agricultural cycle. But, in that case, one must explain how the rite ever successfully established itself at that critical period in the first place. Here, too, it seems preferable to imagine a change having taken place, one that made the rite that much more difficult to maintain, namely, centralization.

${ }^{71}$ See Jeffrey Tigay, Deuteronomy (JPS Torah Commentary; Philadelphia: The Jewish Publication Society, 1996) 155.

${ }^{72}$ Levinson argues that the law commands the pilgrim to return home after the first day of the Passover and observe there the unleavened bread laws (Deuteronomy and the Hermeneutics of Legal Innovation, 53-57). For a strong critique and an alternate reading of the text, see Shimon Bar-On (hereinafter: Gesundheit), Festival Legislation in the Torah: A Literary-Historical Analysis of Exod 12:1-20, 21-28; 23:14-19; 34:18-26; Deut 16:1-8 (Ph.D. diss., The Hebrew University, 1999) 144-240 [Hebrew]; translated and abbreviated in "Der deuteronomische Festkalendar," in Das Deuteronomium (ed. G. Braulik; OBS 23; Frankfurt am Main: Peter Lang, 2003) 57-68.

${ }^{73}$ Shmuel Safrai, "The Pilgrimage Commandment," in The Pilgrimage in Second Temple Times: An Historical Monograph (Tel Aviv: Am Hasefer, 1965) 24-41 [Hebrew]; repr. with addenda in In the Days of the Temple and in the Days of the Mishnah: Studies in the History of Israel (2 vols.; 
being "in Jerusalem" at the time of the Passover comprises two opinions: either "Jerusalem" encompasses whatever sits within a twenty-eight kilometer radius, or "Jerusalem" is none other than the temple itself, and one must already be on the other, holier side of the threshold of the temple precincts to activate the requirement. ${ }^{74}$ Safrai concludes:

Tannaitic law, according to most Tannaim, interprets the concept of being too far away in symbolic terms and in practice transforms the Passover into a voluntary matter. ${ }^{75}$

As a matter of fact, 2 Chronicles 30, a Second Temple composition that reflects the ritual conceptions and practices of its time, depicts just this mentality as characteristic of Second Temple Yehud. As stressed above, the people at first did not attend Hezekiah's Passover in Jerusalem because they recognized no obligation to do so; in the words of the narrator at the end of v. 5 (and not as part of the preceding proclamation): "not often did they act in accord with what was written," namely, to congregate in Jerusalem for the Passover as enjoined by Deut 16:1-8 (and illustrated by $2 \mathrm{Kgs} 23: 21-23) .^{76}$

In this context one may also understand the series of variants in the textual tradition (granting the otherwise standard assumption that later manuscripts preserve Second Temple scribal activity, which in this case actually makes more sense). ${ }^{77} \mathrm{At}$

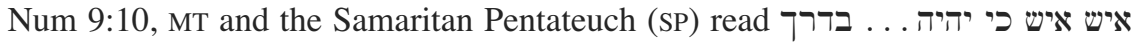
רחקה, according to which the adjective "distant" (רחקה) modifies the immediately preceding noun "road" (דרך): "anyone who is ... on a distant road." LXX MS B

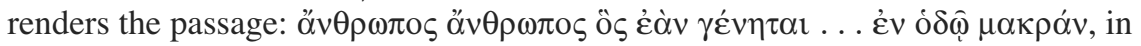

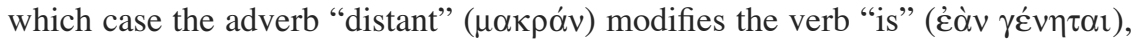
and, now in apposition to the prepositional phrase "on a road" ('่v ó $\delta \hat{\omega})$, serves in an explanatory capacity: "anyone who is . . on a road, i.e., far away." Nowhere does this change indicate that the person is only temporarily "on the road." In line

Jerusalem: Magnes, 1994) 1:43-60 [Hebrew]. Consistent with the centralization framework posited here, Safrai's survey turns up that the Babylonian Talmud reverts to the straightforward meaning of the Pentateuchal pilgrimage passages; since the Babylonian amoraim lived without any temple whatsoever, they had no motive or determinative realia pushing them to interpret otherwise.

${ }^{74}$ See, for example, m. Pesah. 9:2; Sipre \$69. According to an amazing anecdote in b. Pesah. 70b, one sage went south before the onset of Passover in order to escape the obligation to perform it.

${ }^{75}$ Safrai, In the Days of the Temple and in the Days of the Mishnah, 1:57.

${ }^{76}$ It would appear that pilgrimage enjoyed something of an upsurge in Hasmonean and especially Herodian times. See Martin Goodman, The Ruling Class of Judea: The Origins of the Jewish Revolt Against Rome A.D. 66-70 (Cambridge: Cambridge University Press, 1987; repr. Cambridge: Cambridge University Press, 1993) 50-58; "The Pilgrimage Economy of Jerusalem in the Second Temple Period," in Jerusalem-Its Sanctity and Centrality to Judaism, Christianity, and Islam (ed. L. I. Levine; New York: Continuum, 1999) 69-76; Seth Schwartz, "Herod, Friend of the Jews," in Jerusalem and Eretz Israel: Arie Kindler Volume (ed. J. Schwartz et al.; Ramat Gan: Bar Ilan University, 2000) 67-76; idem, Imperialism and Jewish Society, 200 B.C.E. to 640 C.E. (Princeton: Princeton University Press, 2001) 40-62, 94-95.

${ }^{77}$ The translations in this paragraph are mine. 
with the mentality charted by Safrai and seen in Chronicles, the new text could refer to - indeed serve - those living far away on a permanent basis. ${ }^{78}$ The complete erasure of the adjective "distant" in MT and SP at v. 13 (contrast tellingly LXX) would further expand the bounds of those who can perform the Passover on the secondary date to include anyone living "on a road," namely, not in the vicinity of the temple or the temple city. The dot over the letter ה in MT at v. 10 (רחקה) could have meant to signal either possibility - erasure of the $\mathrm{i}$ alone as in $\operatorname{LXX}^{79}$ or of the entire word as in MT and SP at Num 9:13. ${ }^{80}$

Safrai never actually ventures an explanation of how this state of affairs - both on the ground and in textual hermeneutics - ever came about. But the very terms of his discourse, together with the text-critical data, could not indicate more clearly that behind it all stands the reality of a single solitary temple physically far from most of the people - to wit, a reality created by cultic centralization.

When taken together - the Deuteronomic code's resistance to altering the Passover to make it easier for the farmer; the fact that in the Second Temple period, Jews rarely went on pilgrimage to celebrate the Passover at the temple; and the rabbinic reinterpretation of pilgrimage as a voluntary matter-all these converge to point towards an explanation for the rise of the law of the Second Passover. The centralized cult in Jerusalem made the distance to the single temple too far for many farmers to trek there with their families for Passover, especially in the difficult period towards the unpredictable end of the rainy season on one hand and the delicate beginning of the grain harvest on the other ${ }^{81}$ Sources attest that during these times, in order to bolster popular participation in the temple Passover, Judean authorities - not entirely unlike Chronicles' Hezekiah - would intercalate a month depending on precisely these same two factors: if the barley ripened late or the rains made the roads impassable. ${ }^{82}$ The law of the Second Passover attempted to achieve the same result through a different means - by providing individuals with an alternate, secondary date, one month later. ${ }^{83}$

${ }^{78}$ If the variant was created by the translator, it would reflect the needs of the Alexandrian community itself, at least rhetorically and ideologically, since in practice an annual Passover pilgrimage would seem be even more distant than for those living within Yehud. The variant more likely reflects

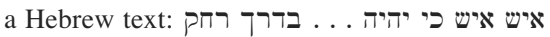

${ }^{79}$ See Dillmann, Numeri, Deuteronomium und Josua, 46.

${ }^{80}$ See Knobel, Numeri, Deuteronomium und Josua, 38.

${ }^{81}$ On the unpredictable end of the rainy season, see Dalman, Arbeit und Sitte in Palästina, $2: 15$; on weather conditions as a factor in the extent of any given year's Passover pilgrimage, see in general terms Feliks, Agriculture in Eretz-Israel, 186-87; in specific terms, Milgrom, Leviticus, 3:1999-2001. On the many and varied challenges besetting the farmer during harvest season, see David C. Hopkins, The Highlands of Canaan: Agricultural Life in the Early Iron Age (Sheffield: Almond, 1985) 223-27; Feliks, Agriculture in Eretz-Israel, 186-88, 194.

${ }^{82}$ B. Zuckermann, "Materialen zur Entwicklung der altjudischen Zeitreichnung im Talmud," Jahersbericht des juidisch-theologisches Seminar in Breslau (1882) 39; Elias J. Bickerman, "Calendars and Chronology," in The Cambridge History of Judaism, 1:60-69, at 65.

${ }^{83}$ Contrast Rofé, who remarked on the relationship between the law of the Second Passover and Deuteronomy with regard to the concern for proximity but presumed Deuteronomy to have 
In this case, then, the pivotal phrase בדרך רחקה in MT Num 9:10 did not originally mean "on (i.e., in the midst of) a distant journey." ${ }^{84}$ Rather, the phrase originally meant "on (i.e., along) a distant road" or perhaps "on a difficult road," 85 in line with the rabbinic lore cited above about how far from the temple constitutes "too far" for one to be required to bring the Passover. ${ }^{86}$ And the shifting textual traditions surveyed above represent not changes in the phrase's meaning, but rather a series of attempts to remove its ambiguity and refine its sense with greater specificity.

What comes to the fore so strikingly in this analysis is the realization that the emphasis in the law of the Second Passover falls not on sympathetically freeing the Israelite from bringing the Passover on time, but rather on insisting that he bring it sometime. Like the Passover law in Deut 16:1-8, the Second Passover law insists on the obligation to celebrate the Passover at the temple every year. It denies one's right to view the sacrifice as a voluntary matter, rejects the standing waiver the people applied to themselves, and refuses to compromise on the Passover's annual character. It does not represent the leniency projected by the narrative currently framing it (Num 9:6-8), but rather a stringency. Indeed, the Second Passover law is the only biblical text anywhere to state that one who fails to come perform the Passover will suffer כרת

influenced the Priestly law, perhaps to the degree that it led to the interpolation of proximity into it (Introduction to Deuteronomy, 17). Closer to the suggestion made here, Baruch Levine sees centralization behind the law of the Second Passover, but he too argues for Deuteronomic literary influence on Num 9:1-14 (Numbers 1-20 [AB; New York: Doubleday, 1993] 293). However, literary-critical analysis of the passage reveals no Deuteronomic signs whatsoever, the text having been minted purely in the Priestly coin.

${ }^{84}$ See, for example, Knobel, Numeri, Deuteronomium und Josua, 38; Markus P. Zehnder, Wegmetaphorik im Alten Testament. Eine semantische Untersuchung der alttestamentlichen und altorientalischen Weg-Lexeme mit besonderer Berücksichtigung inhrer metaphorischen Verwendung (BZAW 268; Berlin: de Gruyter, 1999) 312-15, esp. 312. Compare biblical idiom in Prov 31:14, , היתה כאניות סוחר ממרחק תביא לחמה , and Prov 7:19, or even the expression בארץ רחוקה in Deut 29:21; Josh 9:6, 9; 1 Kgs 8:41; 2 Kgs 20:14; 2 Chr 6:36. For a briefer semantic study of דרך, but without specific reference to Numbers 9, see Semantics of Ancient Hebrew (ed. T. Muraoka, ed.; Abr-Nahrain Supp. 6; Peeters: Louvain, 1998) 11-37.

${ }^{85}$ Compare, for example, Exod 13:17; Deut 30:11-14.

${ }^{86}$ See m. Pesah. 9:2; Sipre §69; b. Pesah. 70b.

${ }^{87}$ See vv. 13 and 7, respectively. On various grounds it appears that in the original form of v. 7, the plaintiffs argued, למה נגרע מתוך בני ישראל ("Why should we be cut off from among the Israelites?"). So already Abraham Kahana, The Book of Numbers (1914; repr., Jerusalem: Makor, 1969) 28 [Hebrew]. Original $\boldsymbol{Q}$ becomes current $ב$ in one of three possible scenarios: a) text-critical error due to graphical similarity (on 2 interchanges, see Emanuel Tov, Textual Criticism of the Hebrew Bible [Minneapolis: Fortress, 1992] 247-48); b) a copyist's stylistic change due to the interpolation of לבלתי הקריב את קרבן הי במעדו, making the verse's final clause qualify not the now distant verb נגרע but rather the closer verb הקריב; c) an editor's attempt to highlight the significance of all Israel performing the Passover together. In the first two scenarios, the interpolated clause, לבלתי הקריב את קרבן ה' במעדו , could have entered the text at the wrong place, in the middle of the sentence rather than at its end as originally imagined. In the third scenario, it reflects the original intention of the interpolator. Relatedly, on the basis of several considerations, it appears that v. 13 originally concluded with כרת. 
At first glance, the strict approach in this Priestly law appears to diverge widely from that taken with regard to the Pentecost, when Priestly legislators waived the popular requirement altogether by transferring it to the temple priests. In fact, the two solutions represent alternate directions in the application of a single shared notion, one that characterizes the Priestly literature - the essential, concrete nature of the dates anchoring the festivals, with which one may not tamper. By contrast, the Deuteronomic code willingly and deliberately delayed and reconfigured two agricultural festivals. Notably, the D source also immovably fixed the date for Passover observance, having defined it historically rather than agriculturally. ${ }^{88}$

\section{Centralization and Purity}

What, then, about the law's provision for the impure person? How does it fit into the historical reconstruction laid out above? Several possibilities recommend themselves, each of increasing integrality to the specific issue at hand. From the strictly literary point of view, one may take it, at the very least, as a predictable, unremarkable reflex of the law's Priestly provenance and marshall in support of this view the absence of the factor of impurity from the comparable Hittite law. From the point of view of legal logic, one could argue that the provision of impurity serves as the natural, perhaps even necessary, complement to the provision of distance, for together, the two provisions represent and encompass the two categories of obstacles that may prevent any person from participating in the Passover: the physical and the ritual. More forcefully, one can make a historical argument, parallel to that for the provision of distance. In the same context of a reality defined by cultic centralization, sanctity would have played no less a role than proximity in alienating the people from the temple cult. In the absence of a local temple and easily accessible means for purification, the need and concern for purity would plummet severely in terms of daily significance and the people's vigilance would wane.

Again, the Deuteronomic laws, written to take into account a centralized cult, provide telling examples. Though it does not appear to have been interpreted so by scholars, Exod 22:30 forbids (or recommends against) touching the impure carcass of a non-ritually slaughtered animal ${ }^{89}$ by contrast, the Deuteronomic law forbids

${ }^{88}$ This point holds for the current form of Deut 16:1-8. If vv. 1, 3, 4, 6b, and 8 comprise a series of additions, as convincingly argued by Gesundheit (above, n. 73), the possibility exists that originally D did not hold as rigid a view of the Passover date and one of the goals of the editors consisted of providing just such a delimitation of the date.

${ }^{89}$ Surely the law in Exod 22:30 does not command one who chances upon a carcass out in the field to pick it up, carry it somewhere, and there toss it to the dogs. Rather, the expression means "you shall abandon it to the dogs" or "you shall leave it for the dogs." For other instances where ש-ל-ד means "expose, abandon, leave untouched," see Gen 21:15; 37:20 (as opposed to vv. 22, 24 there); Isa 2:20-21; 34:3; also $1 \mathrm{Kgs} \mathrm{13:24,} \mathrm{25,} \mathrm{28;} \mathrm{Jer} \mathrm{14:16;} \mathrm{36:30;} \mathrm{Dan} \mathrm{8:11,}$ several of which were already discussed in Morton Cogan, "A Technical Term for Exposure," JNES 27 (1968) 133-35. On the phenomenon of the semantic extension of verbs from the action itself to the result of that action, see Edward L. Greenstein, "Trans-Semitic Idiomatic Equivalency and the Derivation of Hebrew $m l$ 'kh," UF 11 (1979) 329-36, esp. 335. Incidentally, according to Koehler 
consumption alone and explicitly allows one to handle the carcass and sell it to the non-Israelite (Deut 14:21)..$^{90}$ What the law had first treated comprehensively on the grounds of sanctity, it subsequently broke down as a matter of mere taboo. ${ }^{91}$ By the same token, whereas previously all slaughter of domesticated animals had a sacred aspect to it (as illustrated by 1 Sam 14:32-35) that required one to eat meat in purity (as articulated in 1 Sam 20:24-26), the Deuteronomic abolition of local sacred slaughter (Deut 11:31-12:28) ${ }^{92}$ allowed one to eat domesticated animals in impurity, no different from game $(12: 15,22) .{ }^{93}$

In this desacralized atmosphere, the people could easily slip and arrive at the temple in a state of impurity. Indeed, in Chronicles - which tells of a recentralized cult and was composed during a period of centralized cult - the northern masses, displaying just this secularized state of mind, fall into the trap and eat the Passover in a state of impurity. With no technical, ritual recourse, Hezekiah can only pray to God and beseech him to accept the people's good intentions, which God in fact does, rather than stipulate a procedural remedy (2 Chr 30:18-20). Just as the rabbis' reinterpretation of the pilgrimage laws reflected de facto popular practice, in this instance too the rabbis formalized in principle the forbearance featured in Chronicles; and they did so specifically with regard to the Passover, though by extension to other public offerings as well: "impurity is waived in a public setting." 94 However, average Judeans or Jews, who, with the pilgrimage season upon them, suddenly recall the untended impurities that have accumulated, may not have known or anticipated such leniency, expecting rather priestly rigor in the maintenance of temple strictures and so just as easily have forgone the journey to stay at home. The particular exchange in Hag 2:11-13 suggests that priests may very well have questioned pilgrims. ${ }^{95}$ In such circumstances, the law of the Second Passover would

and Baumgartner, Hebrew and Aramaic Lexicon, 2:1527, the identification of the root ש-ל-ל as the $\breve{S}$ pattern of ה-ל-ל goes back to C. J. Labuschagne in 1971. In fact, Naftali Tur-Sinai had already made the suggestion twenty years earlier, in 1952; see Eliezer Ben Yehuda, A Complete Dictionary of Ancient and Modern Hebrew (ed. H. Ben Yehuda, M. Z. Segal and N. H. Tur-Sinai; 17 vols.; Tel Aviv: La'am Publishing House, 1948-1959) 14:7167 n. 2 [Hebrew].

${ }^{90}$ The Priestly law allows the average Israelite to eat carrion but requires proper treatment of the resulting impurity (Lev 11:39-40; 17:15). Priests, by contrast, may not contract impurity by eating meat of an animal that did not undergo ritual slaughter (22:8). It remains unclear whether this position reflects centralization or a different conception altogether. See, for instance, the discussion in Weinfeld, Deuteronomy and the Deuteronomic School, 225-32.

${ }^{91}$ Note how the motive clause about the people's holiness in Exod 22:30 now frames an entire series of dietary and other laws shorn of the original cultic value in Deut 14:1-21.

${ }^{92}$ For the argument that the section begins in 11:31 and not in 12:1, see Alexander Rofé, Deuteronomy: Issues and Interpretation (London: T\&T Clark, 2002) 97-99.

${ }^{93}$ On some of the broader implications of centralization for sacrality, see Weinfeld, Deuteronomy and the Deuteronomic School, 225-43.

${ }^{94}$ See m. Pesah. 7:4, 6 and 9:4; Sipre $\$ \$ 65,70$; and the many discussions in b. Pesah. 69a-b, $77 \mathrm{a}-80 \mathrm{~b}$.

${ }^{95}$ In this context see also lines 4-5 of the Aramaic "Passover Papyrus" from Elephantine: "And from the fifteenth day to the twenty-first day. . . . Be scrupulously pure." For the text see James M. 
insist that, like the distant farmer, the impure may not take impurity as a waiver and settle in his mind on coming only the following year; he must fulfill his Passover obligation one month after the original Passover date.

\section{Conclusion}

In sum, the law of the Second Passover represents a Jerusalem priesthood living in the unintended fallout from the centralization of the cult, unwilling to give up on the Passover as an annual temple rite. ${ }^{96}$ Narrowing down the period in which the priests may have legislated this law poses a sticky problem that depends on one's view of several overlapping issues, each of which in its own right represents a series of complex historical and literary cruxes: the historical reliability or probability of the centralization reports in 2 Kings 18 and 21-23, the provenance of the Priestly literature, and the character of the Passover sacrifice and its historical development. ${ }^{97}$ Without going into the various problems and theories, suffice it to

Lindenberger, Ancient Aramaic and Hebrew Letters (2d ed.; Leiden: Brill, 2003) 61-63, 65-67; for a reconstruction of its historical context, see Bezalel Porten, Archives from Elephantine: The Life of an Ancient Jewish Military Colony (Berkeley: University of California Press, 1968) 278-82.

${ }^{96}$ The theory advanced here does not depend on the broader question as to whether the Priestly literature in the Pentateuch presumes (an ideology of) centralization. (For some classic statements, see, on one side, Julius Wellhausen, Prolegomena to the History of Israel [trans. J. S. Black and A. Menzies; 2d ed.; Edinburgh: Black, 1885]; Haran, Temples and Temple-Service in Ancient Israel, esp. 132-48, 189-204, 289-348; on the other, Yehezkel Kaufmann, The History of the Israelite Religion [4 vols.; Jerusalem: Bialik, 1937-1957] 1:113-42 [Hebrew]; trans. and abridg. M. Greenberg, The Religion of Israel from Its Beginnings to the Babylonian Exile [New York: Schocken Books, 1960; repr., 1974] 175-89; Milgrom, Leviticus, 2:1503-14.) Two factors limit the relevance of this overarching question to the interpretation of Num 9:1-14. First of all, the profoundly ambiguous nature of the Priestly Passover texts in the Pentateuch-1) two notoriously cryptic calendar entries in Lev 23:5 and Num 28:16 offer no more of a hint as to its character than the brief formulation פסח לה', which recalls typical sacrificial terminology;2) the domestic form detailed in Exod 12:1-11, 22 said in vv. 24-25 to endure for generations but destined in vv. 14-20 to transform into a sevenday "festival" connoting a temple pilgrimage; 3 ) and the seemingly domestic setting envisioned in the land in Exod 12:46-sets the Passover apart as outside whatever framework the Priestly texts have otherwise established for the sacrificial cult, if these texts do not themselves actually debate precisely this point. Secondly, scholars have routinely identified the passage in Num 9:1-14 itself as secondary within the Priestly text (for instance, Carl Steuernagel, Lehrbuch des Einleitung in das Alte Testament [Tübingen: Mohr-Siebeck, 1912] 161 §40, 5d), which allows it its own independent set of presupposed circumstances, as reconstructed here.

${ }^{97}$ The argument does not treat, depend upon, or affect the question as to whether, in the wake of the centralization of sacrifice, the people kept no Passover whatsoever or, despite centralization, kept the Passover at home, presumably continuing something akin to whatever it is that Exodus 12 attests. Suffice it here to survey briefly the meager evidence for a domestic Passover-essentially, Exodus 12, which, moreover, may have conjured up a domestic Passover for historiosophical reasons (see August Knobel, Die Bücher Exodus und Leviticus [KEHAT; Leipzig: Hirzel, 1857] 92-93; Wellhausen, Prolegomena, 102; Haran, Temples and Temple-Service in Ancient Israel, 347-48; but compare Gesundheit, Festival Legislation in the Torah, ch. 2).

It would go too far beyond the available evidence to draw any conclusions from the Passover Papyrus (see above, n. 95). The existing text contains neither the word Passover nor any description of an associated rite, the weight in the text falling substantially on the technical details relating to 
point out one piece of data, that the language of the original Second Passover law arguably recoverable through literary criticism contains no signs of Late Biblical Hebrew. ${ }^{98}$ In any case, it seems appropriate to close by highlighting the innovations introduced by the law of the Second Passover. The very idea of a make-up date for a festival and, on the flip-side of that coin, punishing one who unjustifiably misses the Passover with כרת, together help set the Passover apart as sui generis.

leavened foods during the period of the fifteenth to the twenty-first days of the month (compare lines 4 and 5-9). Indeed, the very scheme of the fourteenth day of the month, on the one hand, and the fifteenth to the twenty-first, on the other, that presumably emerges from lines 4-9 and which could suggest some independent content specific to the fourteenth, does not in fact hold up under scrutiny. In lines 4-5, all that remains of the relatively small amount of space originally dedicated to the fourteenth-less than a single line-specifies only that one count fourteen days. Taken together with the calendrical framework explicitly defined in line 8 as "from sundown [sic!] until the twenty-first," the counting of fourteen days looks like nothing more than a run-up to the evening at the end of the fourteenth and the prohibition against leaven that begins then, exactly like the counting of forty-nine days that leads up to the Pentecost on the fiftieth in Lev 23:14-15. Precisely such a calendrical rubric, defined by the same emphasis on leavened foodstuffs, appears in Exod 12:18-20 and (with slight differences in the specific date) in Ezek 45:21. (In this direction, see the relevant comments in Segal, The Hebrew Passover, 7, 9-10, 221-24; Lindenberger, Ancient Aramaic and Hebrew Letters, 61-62; on Exod 12:18-20, see the instructive analysis in Gesundheit, Festival Legislation in the Torah, 73-143, translated and compressed in idem, "Zur literarkritischen Analyse von Ex 12,21-27," ZAW 107 [1995] 18-30, at 25-26). Significantly, the papyrus comes from Elephantine, where in any case centralization did not have the strongest of holds for the Jews there maintained their own temple.

Likewise, no evidence can be gleaned from the ca. 500 B.C.E. ostracon that says, "Tell me when you will be doing the Passover" (on which reading see E. L. Sukenik and Y. Kutscher, "A Passover Ostracon from Elephantine," Qedem 1 [1942] 53-56, at 55-56 [Hebrew]; Segal, The Hebrew Passover, 8; Lindenberger, Ancient Aramaic and Hebrew Letters, 48). The text gives no indication of any rite performed on the Passover and could refer to the same week of prohibited leaven.

Yet another fifth century B.C.E. ostracon (for the text of which see A. Dupont-Sommer, "Sur la fête de la Pâque dans les documents araméens d'Eléphantine," REJ 7 [1947] 39-51, at 45; Segal, The Hebrew Passover, 8) seems to link the term Passover with inspecting vessels. The rabbis use just such a nomenclature; see, for instance, m. Pesah. 2:2-4; 3:1.

Again, in the absence of other evidence, the vehement tone with which the later Book of Jubilees stresses the temple provenance of the Passover in 49:9-21 does not warrant inferring a live polemic against a domestic Passover (for the text, see R. H. Charles, The Book of Jubilees, or the Little Genesis [London: Black, 1902] 256-57; J. C. Vanderkam, The Book of Jubilees [Louvain: Peeters, 1989] 317-24). Qumran writings do not reflect any awareness of such a practice; the Temple Scroll, for that matter, a sectarian document, explicitly locates the Passover in the temple courts (col. XVII lines 7-9; Elisha Qimron, The Temple Scroll: A Critical Edition with Extensive Reconstructions [Beer Sheva: Ben-Gurion University of the Negev Press, 1996] 27). Rabbinic literature, too, seems ignorant of a domestic Passover; see, for instance, m. Pesah. 4:4; 5-9.

Finally, Num 9:1-14 itself betrays no signs of having been formulated against Exod 12:1-24; to the contrary, its terms and conditions, in the law as well as in the narrative, consistently target one who fails to bring the Passover altogether, not one who does so away from the tabernacle/temple, "in the open” (Lev 17:5).

${ }^{98}$ Noted in Knohl, The Sanctuary of Silence, 90. 